\title{
Palliative Care and Spirituality: Bibliometric Research in Health Field

\begin{abstract}
Ana Carla Cavalcanti de Andrade ${ }^{1}$, Solange Fátima Geraldo da Costa ${ }^{1}$, Ana Aline Lacet Zaccara1, Gilvânia Smith da Nóbrega Morais², Jael Rúbia Figueiredo de Sá1, Jaqueline Brito Vidal Batista ${ }^{1}$, Patrícia Serpa de Souza Batista ${ }^{1}$, Thaís Costa de Oliveira ${ }^{3}$
\end{abstract}

\section{Abstract}

This study aims to analyze the bibliometric indicators on national and international scientific production on palliative care and spirituality in health field. The bibliometric research was conducted in the virtual library SciELO and the LILACS, PubMed and IBECS Databases. Papers available in full-length and published in the period of 2005-2014 were selected resulting in a sample of 50 publications, among which 24 are national and 26 international. The journal that published more frequently on the theme was the Journal of Palliative Medicine. Journals classified with Qualis A2 and B2 stood out. Most of the publications were produced by medical practitioners with master degree. There was a predominance of original papers with qualitative approach coming from educational and research institutions abroad. Results suggest a still incipient amount of publications on Palliative Care and Spirituality in the health area at national and international levels, which demonstrates the need for further studies on this subject.

\section{Keywords}

Palliative Care; Spirituality; Religiosity

\section{Introduction}

Science has as one motivating concern the promotion of healing from a variety of illnesses. However, not all diseases have real possibility of cure despite all scientific and technological progress in health and it is in this context that Palliative Care practices have an important role.

It is important to emphasize that such care is recommended in cases of: advanced, progressive and incurable disease; lack of rea- 
sonable responses to the proposed treatments; intense, multiple, multifactorial or mutant symptoms; great emotional impact on the lives of the patient, family or team of caregivers; and prognosis of death [1].

Palliative care should not be merely considered as an additional and subsequent option to inefficacy of curative treatment, but as a care proposal that values the sick person in all his/her dimensions, that is, biopsychosocial and spiritual. This would thereby contribute to comprehensive and highly qualified care that sees the individuals from a holistic perspective [2].

Among therapeutic modalities used in patients under palliative care is the Spirituality which is related to qualities of the human spirit such as love, compassion, patience, tolerance and forgiveness. Therefore, spirituality is an intimate and personal search for sense and transcendent meaning of life [3].

Recent research has addressed the relationship between spirituality and mental health of individuals in difficult times like the onset of a disease with therapeutic possibilities of cure. The link between these two spheres translates into a lower incidence of depression - including shorter remission after treatment, lower prevalence of anxiety and, hence, a lower rate of suicide - as well as a more satisfactory coping with adverse situations. In this regard, studies show a close relationship between spirituality and enhanced quality of life [4].

Given the evidence, it is not possible to separate completely the patient's spirituality from his/her physical and mental well-being. Professionals of the health team working in palliative care have, therefore, a substantial role in caring for spiritual aspects of their patients.

This research is justified by the importance of Palliative Care and Spirituality in the health scenario, particularly in the care of patients with a disease that threatens life or is in the terminal phase. Additionally, there is a need for dissemination of further studies on the scientific production of this theme in national and international literature.

Given the above considerations, this study aimed to analyze bibliometric indicators on national and international scientific literature of the theme spirituality and palliative care in health and disseminated in online journals in the period from 2005 to 2014.

\section{Methods}

This study consists in a bibliometric research. This kind of research was initially used for measurement of the amount of words, editions of books copies. Over time, it became useful for the analysis of other types of documents, such as papers from scientific journals and it allows for the study of quantitative aspects of production, dissemination and use of recorded information [5].

Bibliometric is used to provide greater visibility to metric studies of recorded information, for example, the chronological evolution of scientific production and the spread of scientific publications. In addition, it is considered an important tool for studies directed to the scientific production of an author, country, journal, institution, among others [6].

The universe of the proposed study was composed of national and international publications disseminated in the period from January 2005 to December 2014 in the virtual library Scientific Electronic Library Online (SciELO) and the databases: Latin American Literature in Health Sciences (LILACS), Public Medline (PubMed) and Spanish Bibliographic Index of Health Sciences (IBECS).

Data collection occurred from January to March 2015. To this end, the following descriptors were used: Palliative Care and Spirituality; Palliative Care and Spirituality. These descriptors were combined with the Boolean operator AND in order to refine the studies that addressed only the desired theme.

The following inclusion criteria were adopted for selection of the sample: papers available in full-length, national and international (Portuguese, 
English and Spanish), published from January 2005 to December 2014. Dissertations, doctoral theses, book chapters and editorials were excluded. Thus, we selected 50 publications.

An instrument for data collection was elaborated by the research authors to help in the analysis of selected scientific production. This instrument contained items pertinent to the study, such as: journal name, vocational training and academic degree of authors, country where the research was developed and respective language, year of publication and descriptors mentioned in the research. Each variable was recorded in a Microsoft Excel spreadsheet. Data were analyzed quantitatively through absolute and percentage frequency and presented in figures and tables.

Data related to descriptors were presented in a conceptual map. This shows the relationship between the thematic axes found in the research. This is a didactic and pedagogical tool that facilitates the cognitive process in the teaching of science and makes its use more clear, with power to recognize misunderstood concepts. Moreover, it is an instrument to support the understanding and to make a more dynamic, collaborative and integrated description of data [7].

\section{Results}

Results are presented through graphics for a better understanding of the proposed study. (Figure 1,

\section{Box 1, Box 2, Box 3, Figure 2)}

Figure 1: Quantitative distribution of papers per year of publication $(N=50)$.

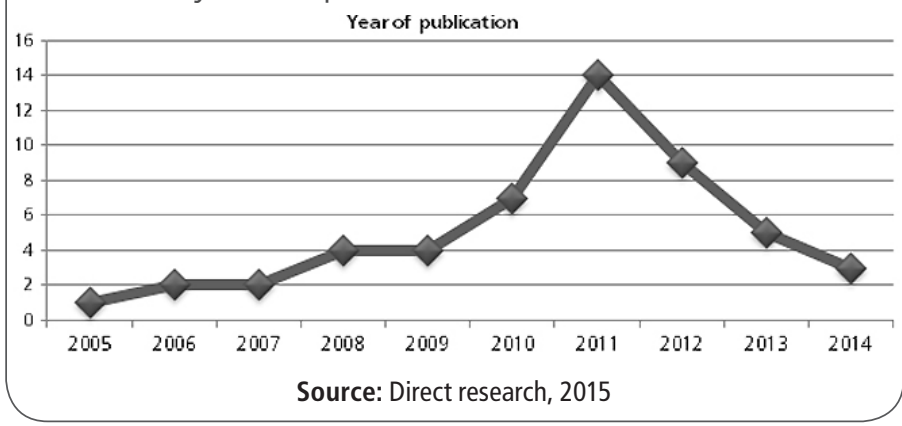

Box 1. Distribution of online journals published in the period 2005-2014 ( $N=50)$.

\begin{tabular}{|l|l|l|}
\hline \multicolumn{1}{|c|}{ Medical journals } & Number & $\%$ \\
\hline Journal of Palliative Medicine & 6 & 12 \\
\hline Palliative and Supportive Care & 4 & 8 \\
\hline Journal of Pain and Symptom Management & 3 & 6 \\
\hline Revista Psiquiatria Clínica & 3 & 6 \\
\hline British Journal of General Practice & 1 & 2 \\
\hline BMC Palliative Care/BIOMED Central & 1 & 2 \\
\hline Surgical Clinicsof North America & 1 & 2 \\
\hline Journal of Pediatric Hematology/Oncology & 1 & 2 \\
\hline Journal Support Oncology & 1 & 2 \\
\hline Contemporary Clinical Trials & 1 & 2 \\
\hline Journal Psycho-Oncology & 1 & 2 \\
\hline Health and Qualityof Life Outcomes & 1 & 2 \\
\hline Evidence-Based Complementary and & 1 & 2 \\
\hline Alternative Medicine & 1 & 2 \\
\hline Quality Safety Health Care & 1 & 2 \\
\hline Boletín Medico Hospitalar Infantil do & 1 & 2 \\
\hline México & 1 & 2 \\
\hline Revista da Sociedade Brasileira de Clínica & 1 & 2 \\
\hline Médica & 1 & 2 \\
\hline Revista Einstein & 1 & 2 \\
\hline Revista HCPA & 1 & 2 \\
\hline Revista Dor & 1 & 2 \\
\hline
\end{tabular}

\begin{tabular}{|l|c|c|}
\hline \multicolumn{1}{|c|}{ Medical journals } & Number & $\%$ \\
\hline Revista Brasileira de Enfermagem & 4 & 8 \\
\hline Acta Paulista de Enfermagem & 3 & 6 \\
\hline CuidArte Enfermagem & 2 & 4 \\
\hline Ciência, Cuidado e Saúde & 1 & 2 \\
\hline Australian Journal of Advanced Nursing & 1 & 2 \\
\hline Revista Latino-Americana de Enfermagem & 1 & 2 \\
\hline Texto Contexto Enfermagem & 1 & 2 \\
\hline Revista da Escola de Enfermagem da USP & 1 & 2 \\
\hline Investigación y Educación em Enfermería & 1 & 2 \\
\hline Enfermagem em foco & 1 & 2 \\
\hline Escola Anna Nery & 1 & 2 \\
\hline Nursing Outlook & 1 & 2 \\
\hline Revista Centro Universitário São Camilo & 1 & 2 \\
\hline
\end{tabular}

Source: Direct research, 2015 
Figure 2: Conceptual map of descriptors in the selected publications and their thematic classes.

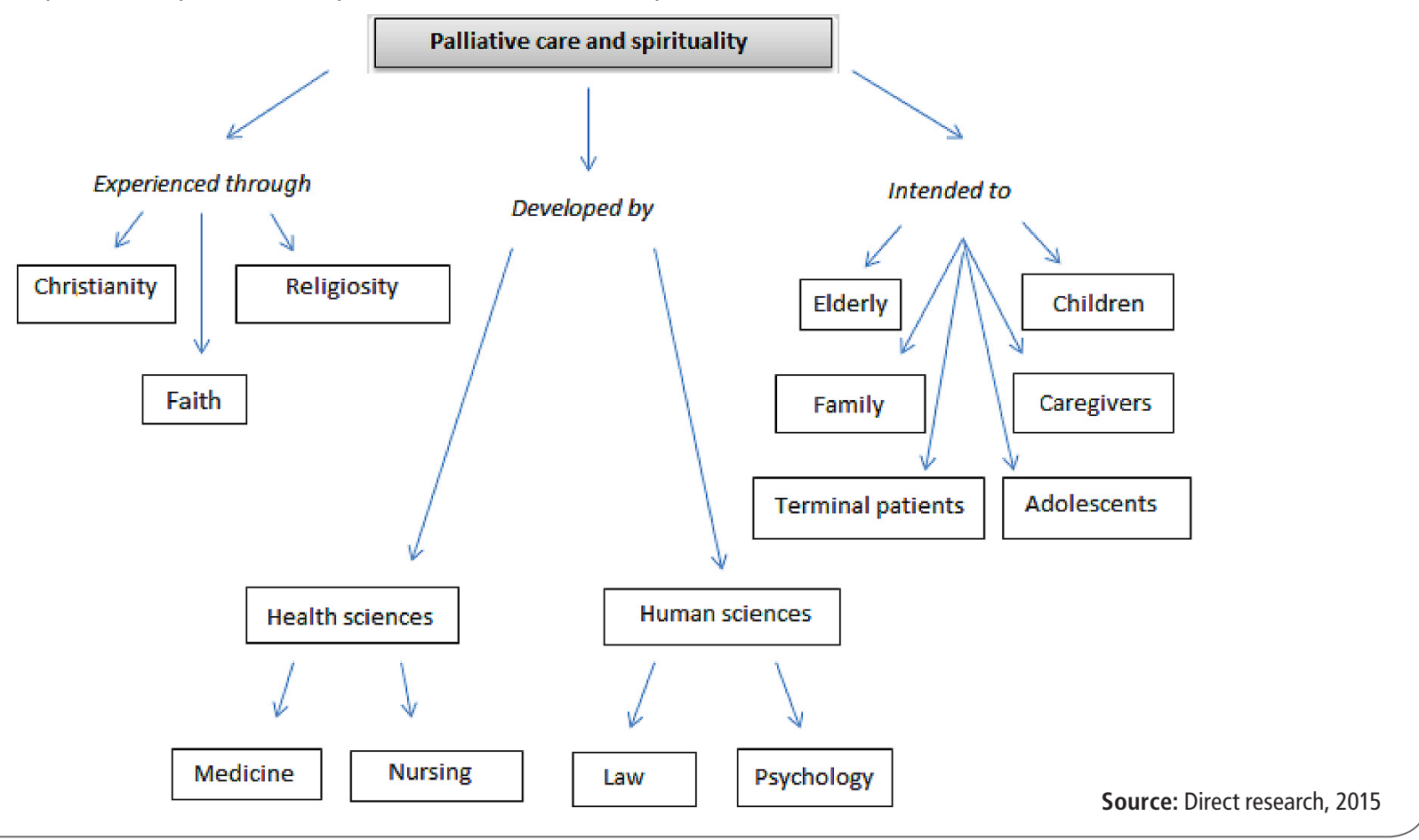

Box 2. Number of authors and their academic degrees based on the studies selected for the research - (Total number of authors $=195$ ).

\begin{tabular}{|c|c|c|c|c|c|}
$\begin{array}{c}\text { Professional } \\
\text { Training }\end{array}$ & Number & $\%$ & $\begin{array}{c}\text { Academic } \\
\text { Degree }\end{array}$ & Number & $\%$ \\
\hline Medicine & 115 & 59 & Doctorate & 70 & 36 \\
\hline Nursing & 73 & 37 & Master & 85 & 44 \\
\hline Psychology & 7 & 4 & Specialization & 57 & 29 \\
\hline
\end{tabular}

Box 3. Distribution of studies on Palliative Care and Spirituality in the period 2005-2014 ( $=50)$ according to country and respective language.

\begin{tabular}{|l|c|c|c|}
\hline \multicolumn{1}{|c|}{ Country } & Number & $\%$ & Language \\
\hline Brazil & 23 & 46 & Portuguese \\
\hline EUA & 15 & 30 & English \\
\hline United Kingdom & 4 & 8 & English \\
\hline Canada & 2 & 4 & English \\
\hline Australia & 2 & 4 & English \\
\hline Germany & 1 & 2 & English \\
\hline Belgium & 1 & 2 & English \\
\hline Mexico & 1 & 2 & Spanish \\
Colombia & 1 & 2 & Spanish \\
\hline
\end{tabular}

Source: Direct research, 2015

\section{Discussion}

Figure 1 shows that the largest number of publications is found on the year 2011 (30.43\%) followed by the year 2012 (19.5\%). It is noteworthy that there is a higher concentration of studies on Palliative Care and Spirituality in the last four years (67.49\%) what demonstrates the recent nature and interest of researchers in addressing spirituality.

As for the journals (Box 1), most of the papers were published in medical journals, particularly the Journal of Palliative Medicine with $12 \%$ of the sample, followed by the Palliative and Supportive Care with $8 \%$ and the Journal of Pain and Symptom Management as well as the Revista Psiquiatria Clínica with $6 \%$ of publications each.

The Journal of Palliative Medicine deals with medical, political, psychosocial and legal issues related to care during the final period of life and the promotion of well-being for patients without possibility of cure, a situation where the spiritual dimension comes into play. The journal also presents important information for professionals deeply interested on palliative medicine, with emphasis on the quality of life of patients and families and spirituality as an 
important influence. Moreover, latest advances in treatments in this area are highlighted [8].

The Palliative and Supportive Care is an international publication of palliative medicine that covers ethical, psychological, psychiatric and existential aspects of Palliative Care. Its main goal is to serve as an educational mean for professionals and researchers who are engaged in caring for patients with life threatening diseases through primary management of symptoms and psychological effects that are fully covered if spirituality is considered. [9]

The Journal of Pain and Symptom Management publishes studies from interdisciplinary areas of palliative care and supports the development of resources that improve clinical practice, evaluating the effectiveness of various therapeutic models in which spirituality operates. Moreover, the journal publishes new technologies currently being developed by medicine related to the practice of palliative care for patients with serious diseases [10].

The Revista Psiquiatria Clínica, also frequent in the present research, disseminates clinical studies that address themes of psychiatry and psychology and contemplate the spiritual aspect, aimed at updating and training of health professionals [11].

Among national journals, the Revista Brasileira de Enfermagem (REBEn) had the highest number of publications, with $8 \%$ of the total. Importantly, REBEn is the official publication of the Brazilian Nursing Association (ABEn). It purposes to propagate scientific production of the most diverse areas of knowledge that might be of the interest to nursing. The inclusion of REBEn in SciELO database enabled visibility and internationalization of the journal and caught attention of foreign authors [12]. In addition, this journal reflects trends of the scientific scenario of the country where the theme spirituality is inserted.

The Acta Paulista de Enfermagem (6\%) is the scientific journal of the Federal University of São Paulo - UNIFESP and disseminates the product of research in the field of Nursing through a rigorous evaluation system aimed at keeping high scientific reliability and accuracy of its publications. [13] UNIFESP has, since 2006, a University Center for Health and Spirituality (NUSE) that brings together academics, professionals of the areas of health, education and management of various sectors, with the main objective of studying the interaction between health, disease and spirituality. In addition, UNIFESP has the Center of Health Sciences History and Philosophy (CeHFi) that offers several mandatory and elective courses for undergraduates in the São Paulo Campus. Among other lines of research, the line Spirituality and Health aims to promote research about the implications of spirituality in health; analyze the role of studying spirituality during undergraduate health training and its implications for professional practice; score and discuss the controversies in the interaction between spiritual practices and healthdisease process.

There was a higher prevalence of studies published in English (50\%), followed by Portuguese (46\%) and then Spanish (4\%). It is worth noting the small number of papers published in Spanish. Based on this information, it is clear that Portuguese-speaking researchers, including Brazilians, have significant access to knowledge about Spirituality and Palliative Care.

With respect to journal classification, there was a prevalence of Qualis A2 and B2, which correspond together to $56 \%$ of the sample. The Coordination for the Improvement of Higher Education Personnel (CAPES) defines Qualis as a formal instrument that lists, classifies and reports the quality of the intellectual production of Master and PhD programs. [14] This reveals the level of quality of scientific production being disseminated about the theme of this scientific manuscript, given that the Qalis measures the quality of papers and other scientific publications.

The Qualis has eight classifications $A 1, A 2, B 1$, $B 2, B 3, B 4, B 5$ and $C$ and the order of magnitude is decreasing, that is, the classification $A 1$ corresponds 
to the highest level and the classification $C$ includes journals with impact index that equals zero [15]. The importance of this system comes from the evaluation of quality of different scientific productions of thousands of researchers. In fact, this evaluation system is used as a key factor to decide on federal grants made available to the scientific community [16].

Concerning the type of publication, original papers $(65 \%)$ predominated and were followed by reviews (31\%) and reflections (4\%). Original papers present topics that may include controlled studies, case studies, diagnostic tests and other descriptive and intervention studies. Thus, original papers need to have depth, quality and must contain the primary data of the results of a survey [17]. Another study mentions that an original paper must be survey never published before, novel to the scientific community [18].

Review papers represent a significant number of publications found in our research. Studies of this type present a systematic and critical judgment of literature on a given subject. [19] They analyze and discuss published material allowing for a re-interpretation of what has been already said.

Reflection papers were less represented in our sample. This type of research expresses the author's point of view about what he sets out to search. That is, the author makes a reflection about what he wants, under his point of view [19].

Box 2 shows the professional training and academic degree of researchers. It was possible to identify different areas of knowledge. The box shows that medical practitioners (59\%) stand out in among authors, since they are directly related to clinical issues involving terminally ill patients under Palliative Care. Nursing (37\%) is the second set of professionals to publish on the topic.

It is noteworthy that $4 \%$ of the publications were developed by psychologists in the field of human sciences. This indicator highlights the interest of researchers from other areas to produce studies on the Palliative Care and Spirituality. It is timely to note that an interdisciplinary team is required to provide comprehensive care to patient coping with diseases without therapeutic possibilities of cure and under terminal phase. Nevertheless, it is observed that physicians and nurses concern with spiritual condition of patients in palliative care is clearly more apparent.

This table also shows that $20 \%$ of authors had a specialization, $44 \%$ had master degree, and 36\% had doctorate. These data demonstrate the link between postgraduate courses strictu senso production and scientific research.

It is important to highlight the difficulty of finding data on academic training and titles of international authors as they are not part of the Lattes Platform and many journals did not bring such information.

As Box 3 shows, most of the papers come from abroad (54\%), particularly the United States (30\%), followed by the United Kingdom (8\%), Canada (4\%), Australia (4\%), Germany (2\%), Belgium (2\%), Mexico (2\%) and Colombia (2\%). This result is evidence that the consistent investment that foreign countries, especially in North America put into their big research centers is a factor that instigates the determination of researchers to publish their studies in this country [20].

In Brazil, most studies were conducted in the state of São Paulo. This happens because São Paulo is a major center of reference in research, in fact, the largest center of research and development in the country. In the sequence come the states of the Federal District and Rio Grande do Sul and, with a less significant number of publications, the states of Pará, Paraná and Bahia.

The participation of Brazil in the setting of research involving spirituality and palliative care in considerable, and can be explained by the fact that Brazil is considered a country of religious plurality. While there have been investments in the field of palliative care, there are few services in this area to 
meet the demand that the nation has. Incentives to provide palliative care in developing countries are, in general, precarious [21].

Descriptors most frequently found in the publications were spirituality and palliative care. This can be explained by use of these terms to search procedure. Thus, Figure 2 exposes the thematic axes defined based on descriptors of the studies. The conceptual map drawn up in sequence covers religious values, professionals from the health and human areas and the group to whom the spiritual care is intended.

The conceptual map allowed identifying three major thematic groups of words related to the ways spirituality is experienced in palliative care, the professions of health and human areas that promote actions and research on the theme and concerning those who receive care. The terms religion, faith and Christianity arose more frequently, as spirituality is linked in most papers to the belief in a superior being. Yet about this group, practices, the relationship with God or a superior being is important for the spiritual assistance in palliative care [22].

Religion provides, in general, a guidance system through which many people deal with stressful life events and in the case of serious illness or the case of Palliative Care [23]. A study suggests that, in the case of people who cultivate faith and religiosity, it is possible to offer care and comforting answers to existential questions. For those who do not have a system of religious beliefs, comfort can provide through solidarity and compassion which help with fears associated with pain, suffering and feeling of being relegated to oblivion after death. Despite the predominant concept of spirituality that is closely related to religion, spiritual assistance must not be limited to dogmatic and doctrinal aspects of an organized system of beliefs according to some studies [1].

Descriptors are notably characterized as related to professional aspects. Professions of the health area, among them medicine and nursing, stood out. Their use as a term seemed to happen when the research had among participants a health professional or when the paper was aimed at a field of knowledge of that specific profession. Papers aimed at knowing the meaning of spirituality, as well as to explore the perspectives and experiences in relation to the spiritual domain to the health team, in personal and professional context, and provide a summary of the different views of clinical practice in spirituality and the use of tools for spiritual history in palliative care.

Other group has to do with those who were receiving the spiritual assistance in palliative care, which were named "terminal patient", taking into account that spirituality is important to offer hope and direction for patients with diseases that threaten the continuity of life [24]. This data points to the abundance of studies on Palliative Care and Spirituality focusing on the patient in face of a terminal illness. Remarkable, too, is the research directed to palliative care in pediatrics and involving family members of ill children. These studies were aimed at understanding how parents of children with life-threatening illnesses turn to religion or philosophy of life and determine the factors associated with their spirituality. [25] The short variety of thematic axes and descriptors suggests that spirituality in palliative care is an area of knowledge still in development.

The discussion above presented shows the growth of research and studies involving the spiritual dimension in the context of palliative care and hence, the endeavor of researchers to address the issue. The human character is closely linked to dignity. Respect it and preserve it means ensuring the individual's vision as rational human being, by understanding the psychological and emotional density of such.

\section{Conclusion}

This research had the aim to analyze the bibliometric indicators of national and international scientific production about Spirituality in Palliative Care during 
the last ten years. A significant number of studies on the subject has been identified in the Journal of Palliative Medicine and in the countries United States and United Kingdom. In Brazil, Revista Brasileira de Enfermagem and Acta Paulista de Enfermagem were the journals that stood out. The vast majority of the studies were published in English, followed by Portuguese. It is worth noting the small number of publications in Spanish. The study underscores the high qualification of the researchers involved in the publications that addressed the spirituality and palliative care, most of which were doctors and masters.

Some gaps were identified in the international studies. This difficulty comes from absence of relevant data for the present research, as professional undergraduate training of the authors and their academic titles. This indicates the need for journals to give more importance to this information, since these data facilitate the characterization of scientific production. It is evident here the importance of bibliometric in the scenario of scientific research. Bibliometric organizes the knowledge of different aspects of the study while announce the gaps, providing direction for further studies and discussions.

The reduced number of publications in national and international scene showed another study limitation. Moreover, there were few thematic axes derived from descriptors found in publications, confirming the limited range of coverage of the studies.

The identified results highlight the importance of further research on spirituality in the context of palliative care and subsequently encourage the inclusion of the topic spirituality in the curriculum of health professionals in order to provide a better quality of life and well-being of patients under palliative care and the family involved in this context.

\section{References}

1. Cervelin AF, Luce Kruse MH. Espiritualidade e religiosidade nos cuidados paliativos: produzindo uma boa morte. Rev enfer UFPE on line 2015; 9(3): 7615-24.

2. Bertachini L, Pessini L. A importância da dimensão espiritual na prática dos cuidados paliativos. Rev Bioethikos 2010; 4(3): 31523.

3. Gussi MA, Dytz JL. Religião e espiritualidade no ensino e assistência de Enfermagem. Rev bras enferm 2008; 61(3): 33784.

4. Lucchetti G, Granero AL, Bassi RM, Latorraca R, Nacif SLP. Espiritualidade na prática clínica: O que o clínico deve saber? Rev Soc Bras Clín Méd 2010; 8(2): 154-8.

5. Jorge JRM, Maia FGM, Viola G. Os principais trabalhos na teoria do conhecimento tácito: pesquisa bibliométrica. In: Anais do Simpoi; 2011, August 24-26; São Paulo. São Paulo: Simpósio de Administração da Produção, Logística e Operações Internacionais, 2011; p. 1-10.

6. Santos, FS. Cuidados paliativos: diretrizes, humanização e alívio dos sintomas. São Paulo: Atheneu, 2011; p. 3-17.

7. Maffra SM. Mapas conceituais como recurso facilitador da aprendizagem significativa-uma abordagem prática [dissertação]. Nilópolis: Instituto Federal de Educação, Ciência e Tecnologia do Rio de Janeiro (IFRJ), 2011. 129p.

8. Journal of Palliative Medicine. Palliative medicine. New York, 2012. Avaliable from: <http://www.liebertpub.com/jpm>

9. Cambridge Journals. Palliative and Supportive Care. USA, 2013. Avaliable from: <http://journals.cambridge.org/ action/ displayAbstract? fromPage $=$ online\&aid $=146933>$.

10. Elsevier. Journal of Pain and Symptom Management. USA, 2015. Avaliable from: <http://www.journals.elsevier.com/journal-ofpain-and-symptom-management/>.

11. Revista Psiquiatria Clínica. A revista. São Paulo, 2014. Avaliable from: <http://www5.usp.br/servicos/revista-de-psiquiatria-clinica/>.

12. Associação Brasileira de Enfermagem. Revista Brasileira de Enfermagem. Brasília, 2013. Avaliable from: <http://www. reben.abennacional.org.br/sobre-noss.

13. Acta Paulista de Enfermagem. Sobre a acta. São Paulo, 2015. Avaliable from: <http://www2.unifesp.br/acta/arevista.php $>$.

14. Silva, RM. O novo qualis, ou a tragédia anunciada. Clinics 2009; 64(1): 1-4.

15. WebQualis. Aplicativo para a classificação dos veículos de divulgação da produção científica da Pós-Graduação Brasileira. Brasília, 2008. Avaliable from: <http://www.bibliotecas.ufu.br/ node/554>

16. Agora é ordem: CGU obriga capes a divulgar planilha completa do qualis de periódicos. [cited 08 July 2015]. Avaliable from: <http://br.okfn.org/2013/05/ 21/agora-e-ordem-cgu-obrigacapes-a-divulgar-planilha-completa-do-qualis-de-periodicos/>.

17. Pereira MG. Estrutura do artigo científico. Epidemiol serv saúde 2012; 21(2): 351-52 
18. Targino MG, Garcia JCR. Conceitos de inédito e original: uso e implicações na comunidade científica. Data Grama Zero Revista de Informação 2012; 13(6).

19. Severino AJ. Metodologia do trabalho científico. 23rd ed. São Paulo: Cortez, 2010; p. 23-258.

20. Neves VR, Sanna MC. Ensino da liderança em enfermagem: um estudo bibliométrico. Acta paul enferm 2012; 25(2): 308-13.

21. Observatório Internacional sobre Cuidados de Final da Vida (IOELC). Global Development [Internet]. United Kingdom: IOELC, 2009 [cited 2013 Dec 23]. Available from: www.eolcobservatory.net

22. Flannelly KJ. Spirituality and Chaplaincy in Palliative Care. J Health Care Chaplain 2012; 18(1): 1-2.

23. Hexem KR, Mollen CJ, Carroll K, Lanctot DA, Feudtner C. How Parents of Children Receiving Pediatric Palliative Care Use Religion, Spirituality, or Life Philosophy in Tough Times. J Palliat Med 2011; 14(1): 39-44.

24. Nelson-Becker H. Spirituality in end-of-life and palliative care: what matters? J Soc Work End Life Palliat Care 2013; 9(2-3): 112-6.

25. Knapp C, Madden V, Wang H, Curtis C, Sloyer P, Shenkman E. Spirituality of parentes of children in palliative care. J Palliat Med 2011; 14(4): 437-43.

\section{Comment on this article:}

\section{f] $[8$ in $8+\mathbf{S}$ P}
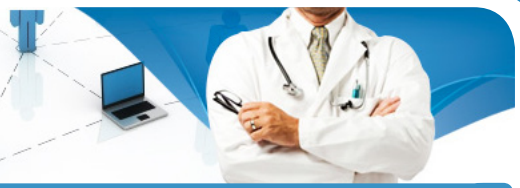

http://medicalia.org/

Where Doctors exchange clinical experiences, review their cases and share clinical knowledge. You can also access lots of medical publications for free. Join Now!

\section{Publish with iMedPub}

http://www.imed.pub

International Archives of Medicine is an open access journal publishing articles encompassing all aspects of medical science and clinical practice. IAM is considered a megajournal with independent sections on all areas of medicine. IAM is a really international journal with authors and board members from all around the world. The journal is widely indexed and classified Q1 in category Medicine. 